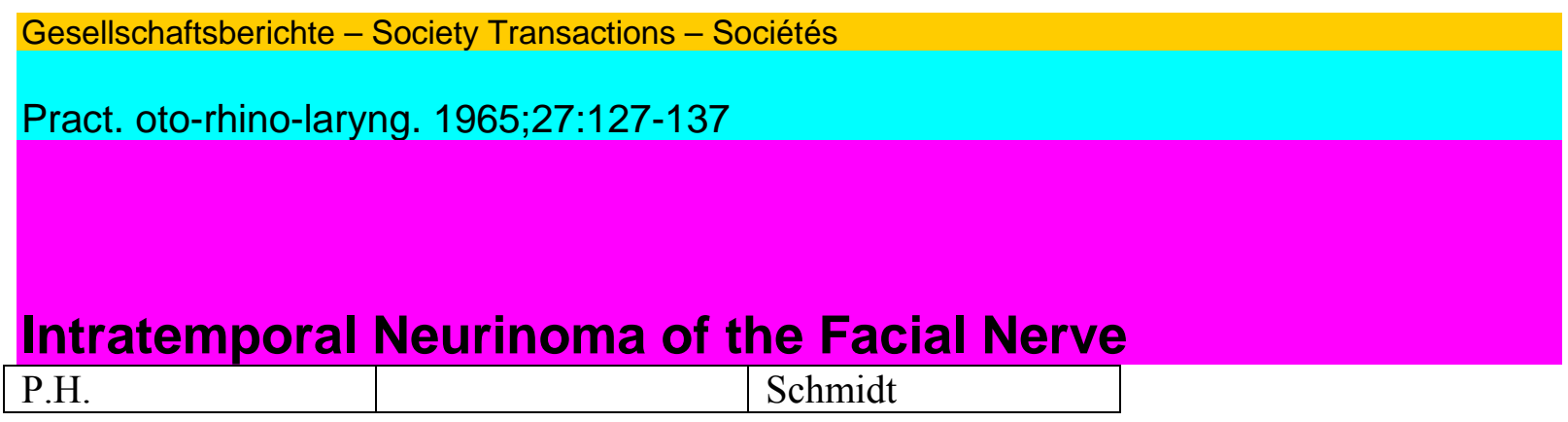

From the Diaconesseninrichting BRONOVO, The Hague

Author's address: P. H. Schmidt, M. D., Diaconesseninrichting Bronovo, Den Haag (Netherlands)

The neurinoma of the facial nerve is a rare tumor. The first case was described by Schmidt in 1930. The fact that 30 years later Miehlke could collect only 42 cases of intratemporal neurinoma of the facial nerve justifies the description of another case.

A 13-year-old girl had noticed a left side facial palsy for 4 months. The palsy had developped within a day. For 3 months she was treated by a neurologist with electrotherapy. After an initial improvement, the palsy had increased and the patient was referred to the otologist. At that time the palsy was complete. There was no pain. The patient did not volunteer any taste difficulty. Beside an acute middle ear infection 12 years ago, there was no history of ear trouble.

Hyperacusis was not noted. There was no pain. The outer ear canal on the left side was squeezed as compared to the round shaped canal at the other side. The bony lining was intact. Both drum membranes were normal. The audiogram showed normal hearing on both ears. X-rays (Stenvers, Schüller, Mayer) showed normal temporal bones. The taste on the anterior two thirds of the left side of the tongue was disturbed.

At surgical intervention the superficial mastoid cells were normal. Between the horizontal canal and the stylomastoid foramen, abnormal tissue was found. It was granulationlike, red, soft and quick bleeding. The facial nerve lost itself diffuse in the tumor. Microscopy showed a neurinoma (Fig. 1).

In the tumor no facial nerve as such was recognizable, so it was resected to in the normal nerve. The middle ear mechanism and the outer ear canal could be preserved. A 30-mm-long graft, taken from the great auricular nerve, was inserted.

General

The neurinoma is a tumor of the peripheral nerve, and may be found in the spinal-as well as in the cranial nerve. One differentiates between the multiple neurinoma (as found in Recklinghausen's "neurofibromatosis") and the solitary neurinoma. 9*

128 Schmidt, Intratemporal Neurinoma of the Facial Nerve 


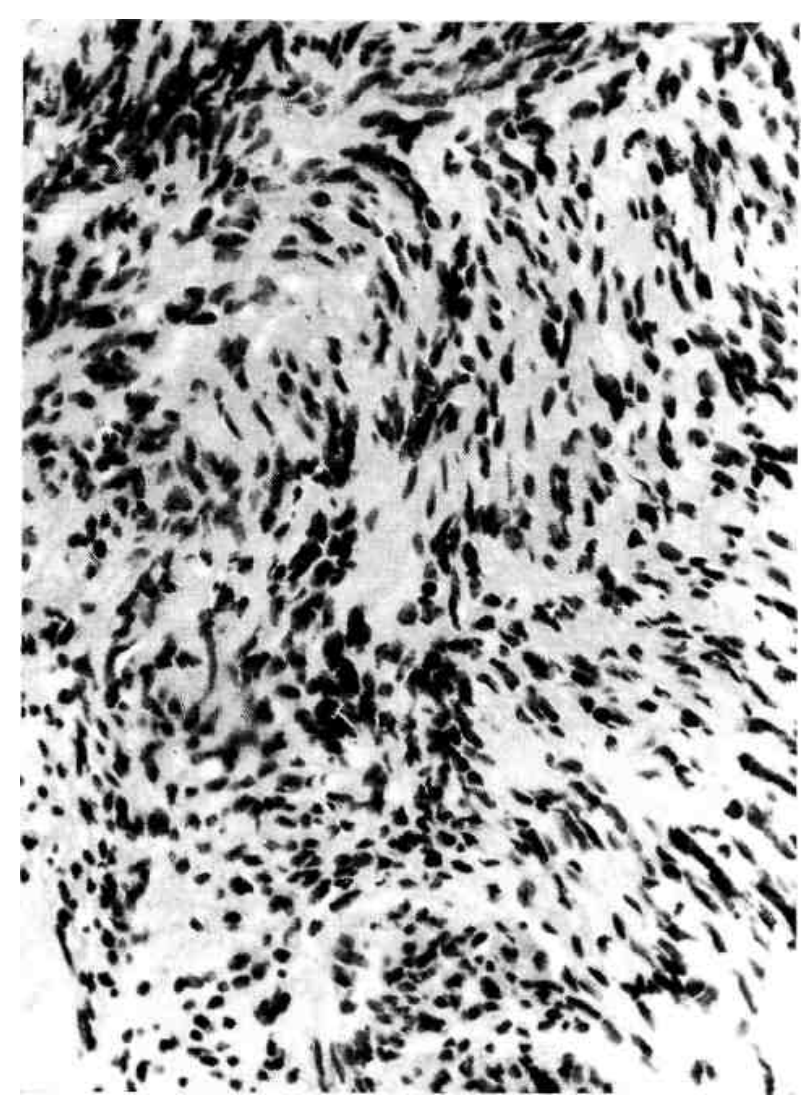

Fig. 1. Neurinoma showing elongated cells with nuclear palisading and eddies.

A peripheral nerve is partly ectodermal, partly mesodermal in origin. Ectodermal are myelin- and Schwann sheath. Mesodermal are epi-, peri- and endoneurium. Recklinghausen thought the "neurofibromatosis" mesodermal in origin.Veroccig (1910), however, made plausible that the tumor is ectodermal; originating from primitive stages of the cells of the sheath of Schwann. On this basis he introduced the name neurinoma and claimed that fibro-neurinoma is a better name than neurofibroma. Despite the fact that multiple neurinoma nearly without connective tissue are described, usually a large quantity of connective tissue is found in the multiple neurinoma.

Schmidt, Intratemporal Neurinoma of the Facial Nerve 129

Probably there is a close connection between multiple-and solitary neurinoma. Some authors, however, claim that a differentiation can be made on the basis of histology. Penfield b.e. says that in the multiple neurinoma the nerve fibres are found scattered through the tumor, while in the solitary neurinoma the nerve fibres are in the tumor capsule only. Most authors, however, reject this opinion and support the statement of Verocay that there is no sure histologic differentiation between multiple- and solitary neurinoma. This leads to the concept that both diseases are essentially the same. Graf defends that the solitary neurinoma is the most moderate and benign expression of Recklingh $<$ aisen's neuro-fibromatosis.

Microscopy shows fibril forming, protoplasma poor cells in crossing bundles. The nuclei are dark coloured and frequently show a palisade arrangement or eddies and streams. Connective tissue may be abundant or scarce in quantity.

Despite this rather characteristic histologic picture, disastrous misinterpretation as "sarcoma" has happened (Roos, Bijars and Ackermann). 
As the development of a neurinoma in a cranial nerve containing only motor fibres is extremely rare, the chances are that a neurinoma of the facial nerve has its origin in the sensory fibres of this mixed nerve.

According to Míehlke, the most frequent origin of a solitary neurinoma is the acoustic nerve. The neurinoma of the $\mathrm{n}$. trige-minus and facial nerve are rare, and the lumor in the n. oculomo-torius, $\mathrm{n}$. accessorius und hypoglossic nerve is extremely rare.

Symptoms and Signs

The symptoms of the neurinoma of the facial nerve depend on the location of the tumor. Extratemporal neurinoma are mostly judged as tumors of the parotid. It should be noted that facial palsy is a relatively late sign in these cases (Maxwell, O'Keeie, Wade, Roos, Bijars and Ackermann).

Bogdasarian pointed out that in the petrous and vertical segments of the Faloppian canal the bony walls are more resistant to expansion than in the horizontal segment. Hence, the onset of paralysis may be earlier with a tumor in either of the former locations than with one in the latter location.

\section{Schmidt, Intratemporal Neurinoma of the Facial Nerve}

In the petrous segment only one proven case is known. It was described by Fehre. As a casual post mortem finding a small neurinoma, located in the internal meatus, completely surrounded by facial nerve tissue was identified. Possibly the tumor described by Tremble and Penfield, which was located along the course of the greater superficial petrosal nerve, just distal to the geniculum belongs to this group. The third and fourth case of Furlow and Walsh probably had their origin in the petrous segment of the facial nerve. However they might just as well have originated in the acoustic nerve.

Most facial nerve neurinoma that have been described, had their origin between the geniculate ganglion and the stylomastoid foramen. Hence, thejr were located either in the horizontal or the vertical portion of the nerve.

In $1937 \mathrm{Al}$ \%mann described the symptoms of the intratemporal facial nerve neurinoma based on seven cases, known in literature at that time. At least one of Ihe cases on which the description was based (Case II from Al†mann 1937) was not a neurinoma. Today it would be named a chemodectoma or glomus jugulare tumor. However, in 1937 the papers of Guild and fiosenwasser still had to be written. The six cases that are left, probably were neurinoma of Ihe vertical portion of the nerve.

In this paper the symptoms and signs as they are reported in the 45 case histories available to-day are given. Unfortunately the description of many cases is insufficient in some and sometimes in many respects.

14 cases have been described where it is clearly stated that the tumor had its origin in the horizontal part.

One of these was a casual finding at autopsy (Greifenstein). In 19 cases there is no doubt that the tumor arose from the vertical portion of the intratemporal course of the facial nerve.

Facial Paralysis

Facial paralysis is mentioned in 35 cases. In only 3 cases a good functioning facial nerve is described (Lundren case I, Pou case I, and according to Lundgren the case of Skoog).

That a small neurinoma may exist without any symptom and thus without a facial paralysis is also known from the case of Fehre, Plester and Wullstein.

Schmidt, Intratemporal Neurinoma of the Facial Nerve 
As the cause of the paralysis is a slow growing tumor, one might expect a gradual onset of the paralysis. This is mentioned 19 times. 8 times however, the paralysis appeared acute. (Altmann case III and IV, Kettel, 1946, Bloch and Aboulker, Graf, Dubs, McAuliffe, Curtín and Lanigan, and the case presented in this paper.) The explanation for this acute onset is obscure. It may be that a bleeding in the tumor is the cause.

Three times it is reported that (witching was the first facial symptom (Bogdasarian, Loelíger case II, Sarkar).

A temporary improvement of the paralysis is described 5 times (Grossman and Leidler, Kotyza, Graf, Dubs, and the case presented in this paper).

A 7-year remission is reported by Kettel (1946).

17 times it is mentioned that the taste in the anterior two thirds of the tongue was disturbed. Only three times (Grossman and Leidler, Furlow and Walsh case I, McAuliffe Curtin and Lanigan) it is stated that the taste was not disturbed. In most case histories this point is not mentioned. It should be realized that the fact that the patient did not notice taste difficulties does not mean that no disturbance could be found at examination.

Age and Sex Distribution

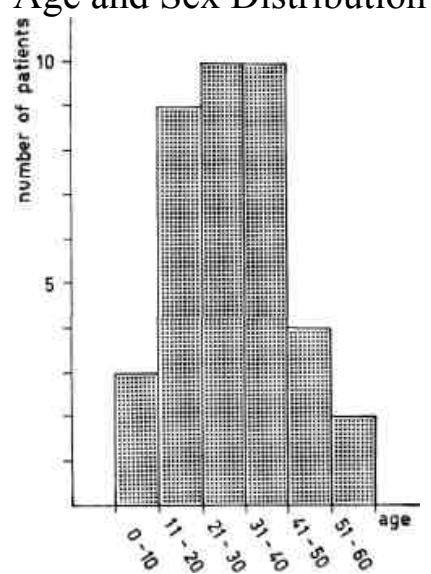

Fig. 2. Age distribution at the time of the first symptom of the intratemporal neurinoma of the facial nerve in 88 patients.

In 37 cases we are informed about the age on which the first symptom was noted. Figure ' 2 represents the age distribution of

132 Schmidt, Intratemporal Neurinoma of the Facial Nerve

these cases. It shows that $75 \%$ of the patients were between 11 and 40 years old when the first symptom appeared. Altmann already mentioned that the tumor was usually found in young people (16-26 years old).

In 40 patients the sex was mentioned. 27 of them were female. This means that only 1 out of 3 cases is found in the male.

Tumor in Outer Ear Canal and Middle Ear

In most cases the tumor presented itself either in the outer ear canal or in the middle ear and frequently in both. Sometimes the tumor had grown from the middle ear to the outer ear canal, sometimes in the reversed direction (Pou, case I). Sometimes a polyplike tumor coming from the middle ear could be seen; sometimes the tumor presented as a polyp, originating in the outer ear canal, lateral from the tympanic membrane. T $\lambda$ vo cases have been described were the tympanic membrane and the outer ear canal were completely normal (Kettel, Caw †horne, case I, as described by Kettel in his monograph). In the case presented in this paper the outer ear canal seemed to be squeezed. The bony lining, however, was intact. 
Deafness

28 times deafness is reported. Only 5 times normal hearing is stated (Kettel, 1946, Collins and Thomson, Cawthome case I, Fur-low and Walsh case II, and the case presented in this paper). With a tumor growing in middle ear and outer ear canal, the deafness will probably have been of the conductive type. Unfortunately, however, information on this point is scarce. In some cases it is stated that the labyrinth was destroyed, the patient dizzy or that the deafness was of the perceptive type (Altmann case II, Williams and Pastore, Pou case II, Jongkees case II, cited by Kettel 1958).

Pain

It is said that these tumors usually do not cause pain. However, the case histories studied do not sustain this statement. 11 times it is reported that there $\Lambda \backslash$ tas no pain; 12 times pain is reported (Grossman and Leidler, Altmann case II and III, Williams and Pastore, Bogdasarian, Kettel, Loeliger case I and II, Pou case I, tháner, Bloch and Aboulker, Kotyzu)

Schmidt, Intratemporal Neurínoma of the Facial Nerve 133

In some of these patients the pain probably was caused by the secondary infection of the middle ear and the outer ear canal. However, in other cases pain is mentioned while there was no such infection (Grossman and Leidler, Williams and Pastor, Kettel, Loeliger case I, Rainer, Kotyza). X-ray Films

A destruction of the temporal bone, seen on the X-ray studies, is reported 14 times (Altmann case III and IV, Williams and Pas-tore, Roberts, Loeliger case I and II, Pou case II, Rainer, Bloch and Aboulker, Lemaitre and Brautman, Jonkees case II as reported by Kettel in his monograph, Kotyza, Graf, McAuliffe Cur-tin and Lanigan). Actually, a destruction is what one might expect from a tumor, located in the temporal bone and growing by expansion. However, frequently no evidence of the tumor was found on the X-ray films (Altmann case II, Bogdasarian, Kettel 1946, Lundgreen, Furlow and Walsh case IV, Dubs, and the case presented in this paper).

The Specimen

A specimen that did not show a neurinoma was reported several times (Schroeder, Altmann case II, Williams and Pastore, Roberts). Sometimes a completely different diagnosis was made (epidermoid cyst in the case of Schmidt 1930, Leiomyoma in the case of Grossman and Leidler). The tumor described by Guttman and Simon was named neurofibrosarcoma by one pathologist and neurofibroma by another.

Findings at Surgic $<\mathrm{d}$ Intervention

The tumor is reported ranging from small, nearly without any destruction of other structures (like in Plester's second case) to big, extending in the middle cranial fossa (Schroeder, McAuliffe Curtin and Lanigan) or with destruction of the labyrinth (Jonkees case II as reported in Kettel's monograph) or with invasion in the soft tissues of the neck (Jonkees, Pou case II, Loeliger case I).

The colour of the tumor has been described as red, yellowish, whitish and dark brown. Red was the tumor found by Kotyza and

134 Schmidt, Intratemporal Neurinoma of the Facial Nerve the case presented in this paper. McAuliffe, Curtin and Lanigan, described the tumor as dark brown. Yellowish was the tumor reported by Williams and Pasture, Loeliger case II, Fur low and Walsh case III. The yellowish colour may be caused by lipoid degeneration in the tumor. Whitish was the tumor in the case of Lundgren reported by Kettel in his monograph.

Discussion 
As differential diagnoses chronic middle ear infection, chemo-dectoma, carcinoma and epidermoid tumor should be mentioned. Rare tumors such as meningeoma within the Faloppian canal (Cawthorne as reported by Kettel in his monograph), sarcoma (Kettel 1930) and neurinoma of the vagal nerve in the jugular foramen presenting itself in the middle ear (Plester) may make the diagnosis impossible before the operation. However, a good representative specimen should produce the correct diagnosis. Beside this it should be borne in mind that every "Bells palsy" can be caused by a neurinoma of the facial nerve. The diagnosis Bells palsy was named "dangerous" by van Oppenraay and "misused" by Walsh. Reading the 45 case histories of the intratemporal neurinoma of the facial nerve, one would like to add the statement that there is no excuse to stay out a "Bells palsy" that lasts longer than four to six weeks.

Clinical Picture

On the basis of the above-mentioned data one might describe the clinical picture of the intratemporal neurinoma of the facial nerve as follows:

The intratemporal neurinoma of the facial nerve is a rare tumor. $75 \%$ of the patients is between 10 and 40 years old, but the tumor can be found in very young children.

Two of every three patients are female.

The most common first symptom is not facial paralysis. This may start gradually, but an acute onset is uncommon.

The next common finding is a tumor in the outer ear canal or in the middle ear. The tumors of the vertical portion usually presents themselfs in the outer ear canal; the tumors of the horizontal part start to invade the middle ear and may produce a swollen or even bulging eardrum.

Schmidt, Intratemporal Neurinoma of the Facial Nerve 135

Due to these growth in the conductive system, the next common symptom is impaired hearing. Pain is frequently found; usually however it is due to secondary infection.

In advanced cases the tumor can invade all adjacent structures, like middle and posterior cranial fossa, the soft tissues of the neck and the labyrinth.

Therapy and Prognosis

Despite attempts of radiotherapy (Schroeder, Grossman and Leidler, Altmann case II, Williams and Pastore) it is generally accepted now that therapy should be exclusively surgical. The prognosis as far as life is concerned is very good, because the solitary neurinoma does not turn maligne. The facial nerve usually will have to be sacrificed. Immediate repair by nerve grafting is obligatory (Ballance and Duel).

Summary

The intratemporal facial nerve neurinoma is a rare tumor. Up till now only 44 cases have been described in literature. An additional case is presented in this paper. The symptoms and signs produced by the tumor are discussed on the basis of the data found in the description of these 45 cases.

References

Altmann, F.: Über neurogene Tumoren des absteigenden Facialisteiles. Mschr. Ohrenheilk. 69: 1032-1948 (1935).

- Zur Kenntnis der Tumoren des absteigenden Facialisteiles. Mschr. Ohrenheilk. 71: 1287-1292 (1937).

Ballance, C. and Duel, A. B.: The operative treatment of facial palsy by introduction of nerve grafts into the fallopian canal and by other intratemporal methods. Arch. Otolaryng. 15: 1 (1932). Bloch, A. et Aboulker, P.: Gliome bénin du nerf facial à evolution intra-mastoidienne et soustympanale. Ann. Oto-Laryng., Paris 57: 753-754 (1938). 
Bogdasarian, R. M.: Neurinoma of the facial nerve. Arch. Oto-laryng. 40: 291-294 (1944).

Collins, E. G. and Thomson, I. S.: Neurofibroma of the facial nerve. Excision with nerve graft. J. Laryng. 67: 48-50 (1953).

136 Schmidt, Intratemporal Neurinoma of the Facial Nerve

Dubs, R.: Zur Klinik des Facialisneurinoms. Pract. oto-rhino-laryng. 24:

157-165 (1962). Fehre, W.: Beitrag zur Kasuistik der primären und sekundären Tumoren des

Schläfenbeins. Z. Hals-Nas.-Ohrenheilk. 45: 442-451 (1940). FuyIow, L. T. and Walsh, T. E.: Neurilemmoma of the facial nerve. Laryngoscope 69: 1075-1084 (1959). Furlow, L. T.: The neurosurgical aspects of seventh nerve neurilemmoma. J.

Neurosurg. 17: 721-735 (1960). Graf, K.: Neurinom des Nervus facialis. Pract. oto-rhino-laryng. 16: 374-379

(1954). Greifenstein, A.: Zur Kenntnis der isolierten Facialisneurinome. Arch. Ohr.-

Nas.-KehlkHeilk. 142: 50-53 (1936). Grossman, B. und Leidler, R.: As cited by Kettel (I.e.

1958). Guild, S. R.: A hitherto unrecognized structure, the glomus jugularis, in man.

Anat. Rec. Suppl. 79: 28 (1941). Guttman, M. R. and Simon, M. U.: Neurofibrosarcoma of the facial nerve

involving the tympanomastoid. Arch. Otolaryng. 54: 162-166 (1951). Kettel, K.: Neurinoma of facial nerve. Arch. Otolaryng. 44: 253-260 (1946).

Peripheral facial palsy (Munksgaard, Copenhagen 1958).

Peripheral facial palsies due to tumors. Arch. Otolaryng. 69: 276-292 (1959). Kos, C. M.: Tumor of the facial nerve within the mastoid bone. Ann. Otol.

Rhinol. Laryng. 49: 151-159 (1940). Kotyza, F.: Neurinom des Nervus facialis im Schläfenbein. Mschr. Ohrenheilk.

93: 13-16 (1959). L·emaître, Y. et Broutman: Un cas de Schwannome du nerf facial. Soc.

Laryng.

Hôpitaux, Paris 65 (1939). Loeliget, H. Th.: Über Fazialisneurinome. Acta oto-laryng., Stockh. 35: $543-555$

(1947). Lundgren, N.: Neurinoma n. facialis. Acta oto-laryng., Stockh. 35: 535-537

(1947). Maxwell, J. H.: Extra-temporal repair of the facial nerve. Ann. Otol. Rhinol.

Laryng. 60: 1114-1133 (1951). McAuliffe Curtin, J. and Lanigan, J. P.: Neurolemmoma of the seventh nerve

with intra-cranial extension. J. Laryng. 78: 212-219 (1964). Miehlke, A.: Die Chirurgie des

Nervus facialis (Urban \& Schwarzenberg,

München/Berlin 1960). Ohnisi, Y.: A case of facial neurinoma with facial paralysis. Otologia

(Tokyo)

10: 420-425 (1937); cit. Zbl. Hals-Nas.-Ohrenheilk. 28: 669 (1937). O’Keefe, J. J.: Neurinoma of the facial nerve in the parotid gland. Ann. Otol.

Rhinol. Laryng. 58: 220-225 (1949). Oppenraay, G. A. M. van: The dangerous diagnosis:

"Bell's Palsy". J. Laryng.

73: 133-135 (1959). Plester, D.: Das operative Vorgehen bei den Tumoren des Mittelohres.

Arch.

Ohr.-Nas.-KehlkHeilk. 175: 517-519 (1959). Pou,J. W.: Neurinoma (Schwannoma) of the facial nerve; report of two cases.

Arch. Otolaryng. 69: 48-56 (1959). Rainer, V.: Un cas de neurinome du nerf facial. Ann. OtoLaryng. 71: 770-778

(1954). 
Schmidt, Intratemporal Neurinoma of the Facial Nerve

Roberts, G. J.: Neurinoma of the facial nerve in the middle ear and mastoid;

report of case. Arch. Otolaryng. 37: 62-73 (1943). Roos, D. B.; Byars, L. T. and Ackerman, L. V.: Neurilemomas of the facial

nerve presenting as parotid gland tumors. Ann. Surg. 144: 258-262 (1956). Rosenwasser, H.:

Carotid body tumor of the middle ear and mastoid. Arch.

Otolaryng. 41: 64-67 (1945). Sarkar, S.: Neurinoma of the facial nerve. J. Laryng. 73: 129-132

(1959). Schmidt, C: Neurinom des Nervus facialis. Schweiz. med. Wschr. 12: 190-191

(1931). Schroeder, R.: Neurinom n. facialis. Hospitalstidende 72: 773 (1929). Cit. Kettel

I.e. (1959). Skoog, T.: Ett fall av neurofibrom å nervus facialis. Nord. Med. 28: 2383-2384

(1945). Cit. Kettel I.e. (1959). Tremble, G. E. and Penfield, W,: Operative exposure of the facial canal with

removal of the greater superficial petrosal nerve. Arch. Otolaryng. 23:

573-579 (1936). Verocay, J.: Zur Kenntnis der «Neurofibrome». Beitr. path. Anat. 48: 1-69

(1910). Wade, J. S. H.: Neurinoma of the facial nerve simulating parotid tumor. Brit.

J. Surg. 39:86 (1951). Walsh, Th. E.: Bell's palsy: A much misused diagnosis. Laryngoscope 71:

761-764 (1961). Williams, H. L. and Past ore, P. N.: Neurofibroma of the facial nerve in the facial canal. Destruction of the labyrinth and mastoid process. Arch. Otolaryng. 29: 977-981

(1931). Wullstein

H.: Personal communication to Miehlke I.e. 